\title{
Hypopituitarism Secondary to an Arachnoid Cyst - Case Report
}

\section{Hipopituitarismo secundário a um cisto aracnoide - relato de caso}

\author{
Eliezer Abreu Cunha ${ }^{1}$ Anderson Rodrigo Souza ${ }^{1}$ Manoel Jacobsen Teixeira ${ }^{1}$ \\ Eberval Gadelha Figueireido ${ }^{1}$ \\ ${ }^{1}$ Division of Neurosurgery, Faculdade de Medicina da Universidade de \\ São Paulo (FMUSP), São Paulo, SP, Brazil \\ Arq Bras Neurocir 2018;37:128-130. \\ Address for correspondence Eliezer Abreu Cunha, Divisão de \\ Neurocirurgia, Faculdade de Medicina da Universidade de São Paulo \\ (FMUSP), Av. Dr. Arnaldo, 455 - Cerqueira César, São Paulo, SP, 01246- \\ 903, Brazil (e-mail: eliezer_cunha@hotmail.com).
}

\begin{abstract}
Keywords

- arachnoid cysts

- hypopituitarism

- sellar

\section{Resumo}

\section{Palavras-chave}

- cistos aracnoides

- hipopituitarismo

- selar

Arachnoid cysts (ACs) are a rare condition of mass effect injury and are usually found in the Sylvian fissure. However, rarely, they can appear in the sellar area, causing symptoms of compression. Due to the mass effect, the sellar arachnoid cyst (SAC) may cause headaches, visual disturbances, hypopituitarism, precocious puberty, and the "bobble-head doll" syndrome.

We present the case of JNS, 61 years old, male. The patient presented with hypotestosteronism, hypothyroidism, hypocortisolism and bitemporal hemianopsia. The magnetic resonance imaging scans revealed a mass above the pituitary gland, compatible with a SAC. A surgical excision was performed with removal of the capsule and fenestration within the subarachnoid spaces for emptying the cyst. After the procedure, the patient presented great clinical improvement. The rarity of the case calls attention to the fact that SACs should be thought of as a differential diagnosis in cases of hypopituitarism.

Cistos aracnoides são uma condição rara de lesão de efeito de massa e que comumente aparecem na região da fissura silviana. No entanto, raramente, podem aparecer na região selar, ocasionando sintomas de compressão. Devido ao efeito de massa, podem causar dores de cabeça, distúrbios visuais, hipopituitarismo, puberdade precoce e síndrome da "bobble-head doll."

Apresentamos o caso de JNS, 61 anos, do sexo masculino. Paciente com hipotestosteronismo, hipotiroidismo, hipocortisolismo e hemianopsia bitemporal. As imagens de ressonância magnética (RM) revelaram uma massa acima da hipófise, mostrando um cisto aracnoide selar. O paciente foi submetido a excisão cirúrgica com fenestração dentro dos espaços subaracnoides para esvaziamento do cisto e apresentou grande melhora clínica após o procedimento. A raridade deste caso chama atenção para o fato de que o cisto aracnoide selar deve ser considerado como um diagnóstico diferencial em casos de hipopituitarismo.
\end{abstract}

received

December 1, 2017

accepted

January 23, 2018

published online

April 18, 2018
DOI https://doi.org/

10.1055/s-0038-1642605. ISSN 0103-5355.
Copyright (e 2018 by Thieme Revinter

Publicações Ltda, Rio de Janeiro, Brazil
License terms

(c) $(1) \$$ 


\section{Introduction}

The arachnoid cyst (AC) is a mass-effect lesion in the central nervous system. Arachnoid cysts can expand in the space between the pia-mater and the arachnoid membrane (subarachnoid space). ${ }^{1}$ They correspond to $\sim 1 \%$ of all intracranial lesions (with mass effect) in adults and $\sim 3 \%$ in children, with an occurrence of 5 in 1,000 autopsies. ${ }^{2}$ In most cases, ACs are present at birth (congenital); therefore, they are sometimes also called primary. The other cases are called secondary cysts. Approximately half of the cases occur in the Sylvian fissure area, and $9 \%$ of the cysts are located in the sellar and suprasellar regions. ${ }^{1,2}$

Arachnoid cysts, for the most part, are asymptomatic and are usually found during imaging tests. However, due to their mass effect, they can cause headaches, visual disturbances, hypopituitarism, precocious puberty and "bobble-head doll" syndrome. $^{2}$ Due to their rarity and symptomatology of hypopituitarism, it is necessary to report such cases in order to better understand their physiopathology and surgical outcomes.

\section{Case Report}

JNS, 61, started the picture with low libido, sexual dysfunction, asthenia, weakness and constipation. The endocrinologist did hormonal dosage, resulting in hypotestosteronism (150 ng/dL) and hypothyroidism (TSH $2.3 \mu \mathrm{g} / \mathrm{dL}$; FT4I $0.5 \mathrm{ng} /$ $\mathrm{dL}$; T3 $55 \mathrm{ng} / \mathrm{dL}$ ), beginning with hormone replacement. The endocrinologist ordered magnetic resonance imaging (MRI) one year after the onset of the condition. The MRI scans showed a sellar arachnoid cyst (SAC) compressing the pituitary gland and chiasm. It is important to remember that MRI is the exam of choice for diagnosis of AC. ${ }^{2}$ Subsequently, he developed laboratorial hypocortisolism $(4.2 \mu \mathrm{g} / \mathrm{dL})$ and visual disturbance of partial blindness, in which vision is missing in the outer half of both the right and left visual fields, presenting a clinical picture of hypopituitarism, and bitemporal hemianopsia. Surgical treatment was indicated, and the excision was performed with removal of the capsule and consequent fenestration within the subarachnoid spaces for cyst emptying. The result was an improvement in the clinical picture (-Fig. 1A-B and - Table 1).

\section{Discussion}

Due to the rarity of the SAC, it is necessary to discuss this subject so that it is better understood. Arachnoid cysts, for the most part, are asymptomatic and are usually found during imaging tests. When symptoms occur, they are linked to the compression of structures by mass effect. The main location of the cysts is in the Sylvian fissure, $49 \%$ of the cases, later it is cerebellopontine angle, with $11 \%$; supracollicular area, with $10 \%$; or vermis, $9 \%$; sellar and suprasellar region, at $9 \%$; interhemispheric fissure, with $5 \%$; cerebral convexity, $4 \%$ and interpeduncular fossa, $3 \%{ }^{3}$ In the case of our patient, the localization was sellar, which generated the compression of the pituitary and the optic chiasm.
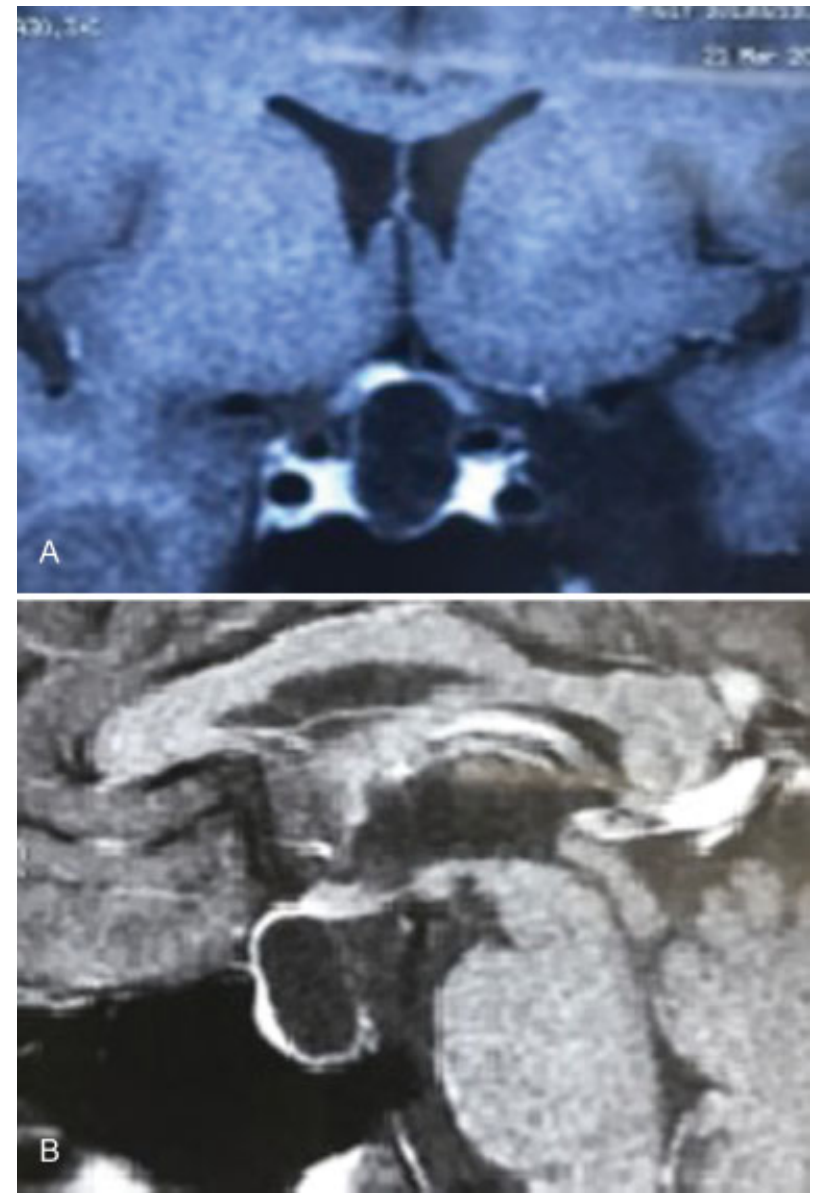

Fig. 1 (A, B) Magnetic resonance imaging scan showing arachnoid cyst with hyposignal at T1 in coronal cut (F1) and sagittal section (F2). Note the compression of the pituitary gland.

There is some discussion about the etiology of SACs. It has been suggested that they develop between the layers of the arachnoid, as well as other intracranial ACs; thus, it would originate above the diaphragm and expand through its aperture or would develop from an under-diaphragmatic arachnoid layer. ${ }^{4}$ Another hypothesis is that it originates from a defective diaphragmatic membrane through which there is a herniation of the arachnoid membrane, this defect may close due to meningitis, inflammation or hemorrhage creating a non-communicating cyst. ${ }^{5,6}$

Table 1 Dosing og hormones

\begin{tabular}{|l|l|l|}
\hline Hormone & $\begin{array}{l}\text { At the time } \\
\text { of diagnosis }\end{array}$ & $\begin{array}{l}\text { After the } \\
\text { treatment }\end{array}$ \\
\hline Free thyroxine index & $0.5 \mathrm{ng} / \mathrm{dL}$ & $1.6 \mathrm{ng} / \mathrm{dL}$ \\
\hline Total T3 & $55 \mathrm{ng} / \mathrm{dL}$ & $93 \mathrm{ng} / \mathrm{dL}$ \\
\hline TSH & $2.3 \mu \mathrm{g} / \mathrm{dL}$ & $8.2 \mu \mathrm{g} / \mathrm{dL}$ \\
\hline Cortisol & $4.2 \mu \mathrm{g} / \mathrm{dL}$ & $14.8 \mu \mathrm{g} / \mathrm{dL}$ \\
\hline Free testosterone & $150 \mathrm{ng} / \mathrm{dL}$ & $412 \mathrm{ng} / \mathrm{dL}$ \\
\hline
\end{tabular}

Abbreviation: TSH, thyroid stimulating hormone. 
Considering that the initial condition was presented with hypopituitarism, the research is done with hormonal dosage and with imaging exam, which was performed in our case. Possible differential diagnoses are tumors that compress the pituitary gland, pituitary tumors and vascular alterations, such as apoplexy. Compared with other sellar cystic lesions, such as cystic adenomas, craniopharyngioma and Rathke cyst, SACs are very rare in this location, with few cases reported. $^{7}$

Compared with other intracranial ACs, SACs present at later ages. Headache and visual disturbances are more common to be presented, while endocrine symptoms are less common..$^{5,8,9}$ The SAC is characterized by a pure cystic lesion with no contrast enhancement and no calcification and with a typical spontaneous leakage of cerebrospinal fluid, which is hyposignal on $\mathrm{T} 1$ and hypersignal on T2-weighted images. ${ }^{10}$ The patient presented symptoms of hypopituitarism and compatible imaging exam, showing a rarity in the case due to a greater rarity of the presented symptoms in relation to the usual symptoms, that were not perceived.

The surgical indication for SAC is identical to that of a non-secreting adenoma: signs of compression or severe headache. Transcranial or transsphenoidal pathways, which is the technique most commonly chosen, can be used to establish the diagnosis and remove the lesion. ${ }^{7}$ In this case, there was surgical indication because the patient presented signs of pituitary compression. The minipterional pathway was selected, and the fenestration was performed, in which the $\mathrm{AC}$ communicates with the cistern, draining the fluid and preventing the cyst from growing again. The excision of the cyst wall and fenestration within the subarachnoid spaces allow direct inspection of the cyst and avoid the placement of a permanent shunt in some cases. In the postoperative period, the cyst did not appear on the imaging examination and clinical improvement of the symptoms was observed.

\section{Conclusion}

Although it is a rare cyst in this location, it is a differential diagnosis that must be thought of in cases of sellar lesions as well as in cases of hypopituitarism, even though the AC rarely causes endocrine disorders.

Conflict of Interest

Authors declare no conflict of interest.

\section{References}

1 Murakami M, Okumura H, Kakita K. Recurrent intrasellar arachnoid cyst. Neurol Med Chir (Tokyo) 2003;43(06):312-315

2 Zieliński G, Podgórski JK, Koziarski A, Potakiewicz Z. [Intrasellar arachnoid cyst. A case report and review of the literature]. Neurol Neurochir Pol 2006;40(04):347-352, discussion 353

3 Rengachary SS, Watanabe I. Ultrastructure and pathogenesis of intracranial arachnoid cysts. J Neuropathol Exp Neurol 1981;40 (01):61-83

4 Meyer FB, Carpenter SM, Laws ER Jr. Intrasellar arachnoid cysts. Surg Neurol 1987;28(02):105-110

5 Dubuisson AS, Stevenaert A, Martin DH, Flandroy PP. Intrasellar arachnoid cysts. Neurosurgery 2007;61(03):505-513, discussion 513

6 Hornig GW, Zervas NT. Slit defect of the diaphragma sellae with valve effect: observation of a "slit valve". Neurosurgery 1992;30 (02):265-267

7 Güdük M, HamitAytar M, Sav A, Berkman Z. Intrasellar arachnoid cyst: A case report and review of the literature. Int J Surg Case Rep 2016;23:105-108

8 Shim KW, Park EK, Lee YH, Kim SH, Kim DS. Transventricular endoscopic fenestration of intrasellar arachnoid cyst. Neurosurgery 2013;72(04):520-528, discussion 528

9 Iqbal J, Kanaan I, Al Homsi M. Non-neoplastic cystic lesions of the sellar region presentation, diagnosis and management of eight cases and review of the literature. Acta Neurochir (Wien) 1999; 141(04):389-397, discussion 397-398

10 Elliott RE, Tanweer O, Rubin BA, Koslow M, Mikolaenko I, Wisoff JH. Suprasellar hamartoma and arachnoid cyst. World Neurosurg 2013;80(06):e401-e407 